\title{
Are child guidance clinics an anachronism?
}

\author{
DORA BLACK \\ Department of Child Psychiatry, Edgware General Hospital
}

As societies develop and bring under control the major causes of premature death-infection, starvation, and war-they turn their attention to the quality of life that is preserved by their efforts. Recent epidemiological studies indicate that all is far from well for our young citizens. One fifth or more of adolescents are handicapped by psychiatric disorders $^{1}$ and 1 child in 6 has 1 or more handicapping physical, educational, or psychiatric disorder. ${ }^{2}$ How well are we meeting the needs of these children and adolescents for diagnosis, treatment, support, and education? The answer, at least for psychiatric services, is very poorly indeed. In 1973 less than $1 \%$ of the child population was seen by child guidance and child psychiatric services. ${ }^{3}$ There has been no expansion in recent years, nor is there likely to be given the high cost of these labour intensive services and the cutbacks in funding.

Of course many childhood psychiatric disorders spring from social and political roots that individual practitioners may be unable to alter. But have they tried? A small but telling case is that of the separation of young children from their parents in hospital. The disruption of attachment bonds is a well documented cause of childhood psychiatric disorder, ${ }^{4}$ yet a recent survey ${ }^{5}$ revealed that $29 \%$ of parents were prevented or discouraged from staying in hospital with their children. However cooperative and willing the ward staff, initiating and maintaining improvements in the psychological atmosphere of institutions are helped by the presence of someone with psychiatric knowledge and skills, particularly knowledge of how individuals and institutions function, the patience derived from experience and self knowledge, and some power and status. This presence is absent in many cases. Most child psychiatric sessions in England are not spent in district general hospitals but in child guidance units often geographically remote from hospitals and funded by education departments not health authorities.

Historically the demand for the new specialists (who separated from paediatricians and general psychiatrists only relatively recently) came largely from educationalists faced with unruly children to educate. Because of this child psychiatric sessions were first established in local authority child guidance clinics to advise schools and to work with psychiatric social workers, educational psychologists, and later child psychotherapists. This model imported from the United States was a pioneering one for its time: the first child guidance clinic in the United States started in 1922 and in England in $1927 .{ }^{6}$ But the 'holy trinity', as Kanner called it, of psychiatrist, social worker, and psychologist has eaten up 'countless extra hours in inter-disciplinary communication in situations where one qualified professional could more effectively manage the problem without ending up talking to himself'. ${ }^{\text {? }}$

Child guidance clinics have come in for a good deal of criticism for failing to 'deliver the goods'that is the cure of troubled and troublesome children. ${ }^{8}$ They are unpopular with the public who feel uneasy when they do not understand who is in charge and who worry about confidentiality. ${ }^{9}$ General practitioners and paediatricians prefer to refer their child psychiatric patients to hospital based specialists and child guidance services are poorly used by social services departments. ${ }^{10}$

While many of these criticisms are unfounded or may also be applied to other institutions (few hospitals practice preventive medicine or can cure chronic handicaps) there is fire behind the smoke. Many child guidance teams have lost their way, are unclear about their goals, and have been bombarded by a series of reorganisations, circulars, and rapid changes in their knowledge base that have had the effect of leaving them leaderless and bewildered. The 1974 circular on child guidance 11 effectively abolished medical directors but made no alternative recommendations for leadership. The social work and the National Health Service reorganisations of the early 1970s changed the managers of many of the staff, and in some cases the ownership and administration of the premises. The studies of Brunel University Institute of Organisation and Social Studies revealed chaos in the organisation of clinics $^{1213}$ and it has been impossible for the different disciplines to agree on the organisation of 
child guidance clinics. Rapid advances in treatment techniques $^{14}$ (some as yet unevaluated) have accentuated philosophical differences between individual practitioners and disciplines which are in many cases unreconcilable ${ }^{10}$ and lead to tensions, especially when there is no acknowledged leader to resolve differences. Small isolated child guidance clinics with few or no trainees to challenge dogmatism can easily become entrenched in outdated practices and in the inefficient use of scarce resources without adequate accountability.

The professions have tried to put their houses in order. In 1978 the Royal College of Psychiatrists published a paper on the work of child psychiatrists ${ }^{15}$ and convened a meeting of other disciplines to discuss it. The resultant publication ${ }^{16}$ attempted to understand the causes of dysfunction and made useful recommendations which, if implemented, may help for a time. But it is probable that the concept of child guidance is not appropriate for our times and does not easily enable us to apply the knowledge we now have of the aetiology, management, and prevention of child psychiatric disorder. To do this, consultant child and adolescent psychiatrists and their teams must work more closely with medical and nursing colleagues especially in general practice, paediatrics, obstetrics, neurology, surgery, medicine, and general psychiatry to prevent and mitigate, for example, the harmful effects of illness and handicapping disorders in parents and children, and the effects of parental mental illness on children.

As the training of local authority social workers and educational psychologists is improved and widened, especially in family and behavioural therapy, they should be able to deal with many of the milder behaviour and learning problems presenting in schools and to their agencies. ${ }^{17}$ There remains, however, a substantial number of children and adolescents with severe and persistent emotional disorders or behaviour problems stemming from psychiatric illness or complex familial problems who require the diagnostic and treatment skills of doctors as highly trained and experienced in child and adolescent psychiatry as are other consultants in the health service. The present deployment of child psychiatrists and their dissatisfaction with their work conditions ${ }^{18}$ militates against achieving the excellence of service that these children need and deserve. The Court Committee ${ }^{19}$ recognised that we needed a health district child and family psychiatric service, combining community and hospital services and provided by the National Health Service that did not merely respond to demands but initiated new ways of identifying and helping the large number of children and families with psychiatric problems. Such a service should be able to evaluate its work and be more flexible in training and use of staff. The National Health Service should face the facts of child and adolescent psychiatric disorder and shoulder full responsibility for the child psychiatric service instead of, in many areas, leaving it to local authority education departments because of a historical accident or economic expediency. Recruitment to child psychiatry is poor and unless child psychiatrists can be given the authority and the resources to identify and treat the child psychiatric disorder in their health district and to plan preventive services in association with other health departments and services, the casualties will once again be the inarticulate and underprivileged.

\section{References}

1 Rutter M, Graham P, Chadwick OFD, Yule W. Adolescent turmoil: fact or fiction. J Child Psychol Psychiatry 1976; 17: 35-6.

2 Rutter M, Tizard J, Whitmore K. Education, health, and behaviour. London: Longman, 1970.

3 Kolvin, I. Evaluation of psychiatric services for children in England and Wales. In: Wing JK, Häfner $J$, eds. Roots of evaluation. Oxford: Oxford University Press, 1973.

4 Rutter M, Maternal deprivation reassessed. Harmondsworth: Penguin Books, 1972.

5 Consumers Association. Children in hospital. London: 1980.

6 Renton G. The East London child guidance clinic. J Child Psychol Psychiatry 1978; 19: 309-12.

7 Eisenberg L. Child psychiatry: the past quarter century. Am J Orthopsychiatry $1969 ; 39$ : 389-401.

8 Tizard J. Maladjusted children and the child guidance service. London Educational Review 1973; 2 : 22-37.

9 Burck CA. Study of families' expectations and experience of a child guidance clinic. Brit J Soc Work 1978; 8: 145-59.

10 Black D. Family therapy in child guidance clinics. In: Bentovim A, Gorrell Barnes G, Cooklin, A, eds Family therapy: complementary frameworks of theory and practice. London: Academic Press, 1982.

11 DES/DHSS Child Guidance Circular 3/74/HCS/(15)9. 1974.

12 BIOSS. Future organisation in child guidance and allied work. Uxbridge: Brunel University, 1976.

13 BIOSS. Organisation of services for the mentally ill. Uxbridge: Brunel University, 1978.

14 Graham P. Management in child psychiatry; recent trends. Br J Psychiatry 1976; 129: 97-108.

15 Royal College Psychiatrists. The role, responsibilities and work of the child and adolescent psychiatrist. Bulletin $1978 ; 127-31$.

16 Interdisciplinary Standing Committee. Interdisciplinary work in child guidance. London: Child Guidance Trust, 1981.

17 Graham P. Child psychiatry and psychotherapy. J Child Psychol Psychiatry 1974; 15: 1, 59-66.

18 Royal College of Psychiatrists. Child psychiatrists and the organisation of child guidance clinics. Bulletin 1980; 92-3.

19 Court SDM. Fit for the future: report of the Committee on Child Health Services. London: HMSO, 1976.

Correspondence to Dr Dora Black, Department of Child Psychiatry, Edgware General Hospital, Edgware, Middlesex HA8 OAD. 